\title{
Analisis Artefak Besi dari Beberapa Daerah di Indonesia
}

\section{Sudarti Prijono}

Keywords: journal, archaeology, berkala, Balai Arkeologi Yogyakarta, metal, metallurgy, artifact

\section{How to Cite:}

Prijono, S. Analisis Artefak Besi dari Beberapa Daerah di Indonesia. Berkala Arkeologi, 14(1), 1-6. https:// doi.org/10.30883/jba.v14i1.624

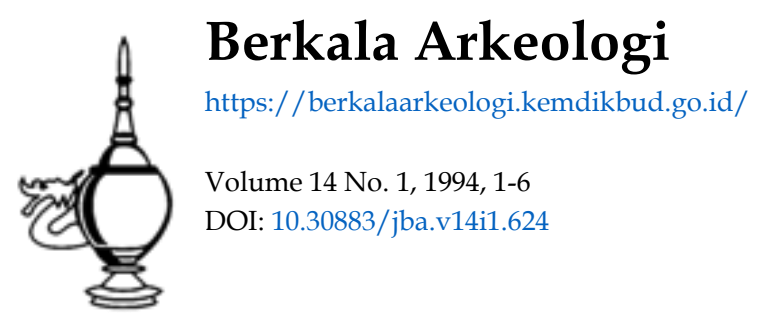

\section{(c) (i) (2)}

This work is licensed under a Creative Commons Attribution-NonCommercial-ShareAlike 4.0 International License. 


\title{
ANALISIS ARTEFAK BESI \\ DARI BEBERAPA DAERAH DI INDONESIA
}

\author{
Sudarti Prijono \\ (Balai Arkeologi Bandung)
}

\section{PENDAHULUAN}

Temuan benda-benda logam dari masa lalu, tersebar di beberapa daerah di Indonesia. Hal ini menunjukan bahwa masyarakat di beberapa daerah tersebut telah mengenal logam dan mungkin juga telah mengenal cara pengolahannya. Artefak besi baik dalam bentuk kerak maupun fragmen alat, merupakan sisa-sisa hasil teknologi masa lalu yang menarik untuk dipelajari secara lebih mendalam.

Seperti diketahui bahwa artefak besi sudah digunakan sejak tahun 2800-2700 Sebelum Masehi oleh orang-orang Asiria dan Mesir. Kemudian di Cina dalam tahun 800-700 Sebelum Masehi ditemukan cara membuat penuangan (cor-an) dari besi kasar yang mempunyai titik cair rendah dan mengandung fosfor tinggi dengan mempergunakan tanur beralas datar. Teknik produksi ini kemudian diteruskan ke negaranegara di Laut Tengah. Cara penuangan pada zaman itu adalah dengan menuangkan logam cair secara langsung kedalam cetakan yang didapat dari bijih besi. Jadi tidak dengan cara mencairkan kembali besi kasar seperti yang dilakukan sekarang (Tata Surdia \& Kenji Chijiiwa, 1986).

Di Indonesia umumnya pada situs-situs presejarah sering ditemukan fragmen-fragmen logam baik yang berasal dari perunggu, emas maupun besi. Hal ini disebabkan karena logam merupakan bahan yang lebih sederhana bila dibandingkan dengan kelompok bahan utama lain seperti keramik dan gerabah. Logam dalam lingkungan teknologi logam berkembang sedemikian majunya, sehingga menjadi perhatian tidak hanya pada masa sekarang tetapi sudah sejak zaman dahulu. Dugaan ini didasarkan pada sifat-sifat, warna, kekuatan, dan kemudahannya untuk dijadikan benda-benda perhiasan, alat-alat dan senjata yang diperlukan dalam kehidupan manusia (Haryono, 1984).

Penelitian mengenai temuan logam seperti perunggu dan logam campuran lain di Indonesia terus dilakukan, baik oleh Pusat Penelitian 
Arkeologi Nasional maupun oleh Balai Arkeologi di daerah untuk lebih mengungkapkan kehidupan dan kegiatan, serta teknologi manusia masa lalu. Salah satu cara untuk mengungkapkan penelitian mengenai temuan logam dengan menganalisis unsur-unsur penyusun kerak dan fragmen besi. Hasil yang diperoleh menunjukan bahwa unsur-unsur pembentuknya adalah Besi (Fe), Mangan (Mn), Silika (Si), Sulfur (S) dan Fosfor $(P)$ dengan perbandingan yang berbeda-beda.

\section{ANALISIS FRAGMEN BESI DAN HASILNYA}

Kerak besi atau fragmen alat besi biasanya merupakan suatu gumpalan atau potongan logam yang berlobang-lobang dan berporipori tidak beraturan dengan permukaan penuh tertutup karat besi serta mempunyai sifat fisik yang rapuh atau mudah patah. Selain itu diketahui bahwa kerak besi adalah merupakan salah satu limbah padat dari kegiatan pertukangan logam besi.

Pelaksanaan analisis fragmen besi kuna dan fragmen besi baru dimaksudkan untuk menentukan jenis-jenis unsur dan komposisi logam pembentuknya untuk mempelajari ciri-ciri logam pembentuknya, serta mempelajari hubungan pengaruh lingkungan terhadap temuan.

Langkah-langkah analisis yang dilaksanakan terdiri dari dua tahap yaitu, tahap pertama adalah analisis kualitatif yang ditujukan untuk memperoleh jenis-jenis logam penyusunnya, sedang tahap kedua adalah analisis kuantitatif, untuk memperoleh komposisi unsur logam pembentuknya. Proses analisis yang digunakan merupakan gabungan dari beberapa metode analisis yaitu, gravimetri untuk menentukan komposisi silika dan sulfur, titrasi volumetri dengan larutan standard kalium permanganat untuk menentukan komposisi mangan serta analisis kolorimetri dengan spectrophotometri untuk menentukan komposisi fosfor.

Pemisahan unsur-unsur untuk diketahui berat tetapnya dilaksanakan melalui cara-cara sebagai berikut. Pertama-tama bahan yang akan dianalisis dibersihkan dari kotoran pengganggu, kemudian dikeringkan pada suhu $105-110^{\circ} \mathrm{C}$ selama 24 jam untuk mendapatkan bahan yang betul-betul kering atau bebas dari pengaruh air. Langkah berikutnya adalah peleburan dengan menggunakan pelarut campuran, dari sini diperoleh hasil leburan yang berbentuk filtrat dan endapan tidak larut, yang dapat ditentukan komposisi silikanya. Dari filtrat dapat diperoleh komposisi sulfur, mangan, fosfor dan besi, 
sedangkan dari endapan tidak larut selain dilaksanakan langkahlangkah tersebut juga dilaksanakan test hilang bakar terhadap bahan untuk mendapatkan komposisi dari bahan-bahan yang mudah terbakar.

Hasil analisis yang diperoleh adalah komposisi dari bahan-bahan kerak besi kuna dan baru serta fragmen dari alat besi yang semuanya merupakan hasil kegiatan survei dan penelitian arkeologi dari beberapa daerah di Indonesia yang dikirimkan pada Balai Arkeologi Bandung.

\section{PEMBAHASAN}

Berdasarkan hasil analisis fisik maupun komposisi unsur dari masing-masing temuan maka perlu dibicarakan mengenai logam campuran dan sifat-sifat dari unsur penyusunnya atau unsur bawaan dari bijih logam dan unsur-unsur tambahan.

Besi yang terdapat di dunia tidak hanya terdiri dari unsur besi saja, melainkan mengandung zat arang dan unsur-unsur lain, sedangkan di alam besi murni hanya terdapat dalam jumlah kecil. Oleh karena itu besi selalu dibuat dari cetakannya, yang setelah diolah akan terjadi besi kasar. Umumnya besi kasar mengandung 3-5 \% C (karbon) dan mencair pada suhu 1100 - $1300^{\circ} \mathrm{C}$ dan tidak dapat ditempa, mengandung silika (Si), Mangan (Mn), Fosfor $(P)$, dan Sulfur (S). Bahan ini mempunyai pengaruh langsung terhadap bentuk besi tersebut. Adanya sifat kimiawi dalam besi akan memperbaiki pemisahan zat arang sebagai grafit, dan menggantikan tempat zat arang. Unsur logam Mn (mangan) hampir di setiap besi kasar akan menghalangi pengaruh silika (Si) karena terdapat sifat kimia Mn hampir serupa dengan $\mathrm{Fe}$, dengan demikian akan mengambil tempat besi, sehingga mengakibatkan bertambahnya besi kasar.

\section{Fragmen Beliung}

Fragmen beliung yang berasal dari situs Buni, Kabupaten Bekasi mempunyai kondisi fisik permukaan bahan tertutup karat besi, berpori-pori, terdapat rongga-rongga yang terisi oleh karat besi, tanah dan sisa-sisa tumbuh-tumbuhan. Hasil pengamatan setelah dilakukan pembersihan ternyata fragmen berwarna abu-abu dan hasil analisis unsur logam $\mathrm{Fe}=68,79 \%, \mathrm{Mn}=1,27 \%, \mathrm{Si}=3,62 \%, \mathrm{P}=12,34 \%, \mathrm{~S}=$ $0,001 \%$ dan kadar LOI (lost of ignation) $=14 \%$. Tingginya kadar LOI dan fosfor $(P)$ bisa terjadi karena;

1. Bahan dasar yang digunakan untuk alat awalnya berasal dari besi 
kasar yang mempunyai titik cair rendah dan mengandung fosfor tinggi, bahan seperti ini sudah digunakan di Cina sekitar 800-700 Sebelum Masehi.

2. Fragmen sudah lama terkontaminasi oleh lingkungan, hal ini terlihat dari tebalnya lapisan karat serta adanya sisa tumbuh-tumbuhan dan tanah yang memenuhi rongga fragmen.

3. Bisa berasal dari saat pengecoran dilaksanakan atau fungsi dari alat tersebut sewaktu dipergunakan.

Hasil analisis unsur terhadap fragmen tersebut terlihat adanya unsur logam $\mathrm{Si}, \mathrm{Mn}$, dan $\mathrm{S}$, ini dimungkinkan karena bijih besi yang terdapat di Alam tidak terdapat dalam keadaan murni.

\section{Fragmen Kerak Besi Buni}

Hasil analisis terhadap kerak besi dari situs Buni menunjukan bahwa kondisi kerak cukup baik tidak berkarat dan berwama abu- abu. Dari hasil analisis unsur diperoleh $\mathrm{Fe}=90,99 \%, \mathrm{Si}=2,71 \%, \mathrm{Mn}=$ $2,05 \%, P=0,24 \%, S=0,001 \%$ dan kadar LOI $=5 \%$, ini berarti kerak besi tersebut belum teroksidasi serta serta tingginya kadar LOI sampai $5 \%$ bisa disebabkan karena terendapkan pada lokasi yang mengandung bahan organik tinggi serta bisa juga berasal saat proses pertukangan berlangsung.

\section{Fragmen Kerak Besi Lampung}

Kerak besi yang berasal dari Situs Pucuk Umun dan Situs Tambah Luhur, Propinsi Lampung sebanyak 2 buah sampel dengan permukaan tertutup oleh karat besi dan ternyata setelah dilakukan pencucian dan analisis unsur terhadap kedua sampel tersebut diperoleh hasil yang berbeda satu sama lain yaitu, sampel dari Situs Pucuk Umun diperoleh komposisi $\mathrm{Fe}=91,08 \%, \mathrm{Si}=2,48 \%, \mathrm{Mn}=$ $4,29 \%, P=10,36$ ppm, $S=0,21 \%$ dan kadar LOI $=1,94 \%$. Sampel Situs Tambah Luhur diperoleh komposisi $\mathrm{Fe}=93,98 \%, \mathrm{Si}=2,29 \%$, $M n=2,96 \%, P=10,36$ ppm, $S=0,10 \%$ dan kadar $L O I=0,67 \%$. Jika dilihat dari sifat kimia unsur logam $\mathrm{Mn}$ yang hampir sama dengan $\mathrm{Fe}$ dimana $\mathrm{Mn}$ mempunyai kecenderungan untuk mengambil tempat $\mathrm{Fe}$ maka sampel dari Situs Pucuk Umun lebih besi kasar dari pada sampel dari Situs Tambah Luhur, sedangkan dari kadar LOI sampel dari Situs Pucuk Umun lebih besar dari pada sampel Tambah Luhur ini berarti sampel dari Pucuk Umun banyak mengandung zat arang ataupun bahan yang mudah terbakar seperti karbon atau hal ini memungkinkan 
sampel dari Situs Pucuk Umun lebih lama terendapkan di lokasi temuan.

\section{Fragmen Kerak Besi Teraju}

Kerak besi dari situs Teraju adalah merupakan kerak besi zaman sekarang, dimana tujuan dilakukannya analisis ini adalah untuk mendapatkan data komposisi logam pembentuknya yang selanjutnya akan dipergunakan sebagai data pembanding terhadap hasil analisis kerak besi masa lalu. Hasil analisis yang diperoleh adalaf $\mathrm{Fe}=91,5 \%$, $\mathrm{Si}=2,20 \%, \mathrm{Mn}=6,30 \%, \mathrm{P}=24,11 \mathrm{ppm}, \mathrm{S}=77,5 \mathrm{ppm}$ dan kadar LOI tidak ada, dari pengamatan terlihat bahwa komposisi unsur logam $\mathrm{Mn}$ dan Si tinggi,serta komposisi unsur logam $P$ dan $S$ sangat kecil dan bahkan kadar $\mathrm{LOI}=0$ ini bisa terjadi karena bahan dasar yang dipergunakan berasal dari besi kasar yang diolah lagi, sedangkan bahan dasar kerak besi kuno berasal dari logam cair yang diperoleh dari bijih besi.

Tidak adanya kadar LOI pada fragmen kerak besi sekarang dimungkinkan karena kerak besi belum mengalami oksidasi serta belum terjadi proses kontaminasi dari lingkungan.

\section{PENUTUP}

Berdasarkan hasil analisis pada pembicaraan yang telah diuraikan diatas dapat disampaikan hal-hal sebagai berikut :

1. Komposisi unsur logam besi ( $F e$ ) pada fragmen artefak besi lebih rendah dari pada komposisi Fe dari kerak besi.

2. Komposisi unsur logam fosfor $(P)$ pada fragmen artefak besi lebih tinggi dari pada komposisi fosfor kerak besi.

3. Kadar LOI pada fragmen artefak besi lebih tinggi dari pada kadar LOI kerak besi, hal ini dapat terjadi jika ada kontaminasi dari lingkungan tempat material terendapkan.

4. Fragmen artefak besi kuna dan keraknya terdapat kadar LOI (lost of ignation).

5. Komposisi unsur logam Mn pada kerak besi kuna lebih kecil dari pada komposisi unsur logam Mn pada kerak besi baru.

6. Komposisi unsur logam Fe pada kerak besi kuna maupun kerak besi baru relatif stabil. 


\section{KEPUSTAKAAN}

Basset, J et al., 1978, Vogel's Textbook of Quantitative Inorganic Analysis. London: Longman Group Limited.

Drayanto, 1983, Ikhtisar Berbagai Macam Logam. Bandung: Tarsito.

Haryono, Timbul, 1984, Analisis Elemental Benda-Benda Perunggu Situs Gunung Wingko. makalah pada Rapat Evaluasi Hasil Penelitian Arkeologi Nasional (PEHPA) II. Cisarua.

Siswandi Ronny, 1985, Alat Produksi Dan Pertukangan Logam Di Banten Lama, makalah pada Pertemuan IImiah Arkeologi III, Ciloto.

Sudarti Prijono., 1991/1992, Laporan Analisis Elemntal Artefak Logam. Bandung: Bagian Proyek Penelitian Purbakala (Tidak diterbitkan).

Tata Surdi dan Kenji Chijiiwa, 1986, Teknik Pengecoran Logam. Jakarta: Pradya Paramita.

Vogel, A. J., 1953, Testbook of Macro and Semimicro Qualitative Inorganic Analysis. London: Weelwich Polytecnic. 